\title{
The Determination Model to Use E-Learning
}

\author{
Dr. M. Ali Iqbal, M.Sc, \\ Senior Lecturer in Magister Management Program, Mercubuana University, Jakarta, Indonesia \\ Dra. Yanti Murni, MM, \\ Senior Lecturer in Faculty Economic, Mercubuana University, Jakarta, Indonesia \\ Dr. Ahmad Badawi Daluy, MM, \\ Senior Lecturer in Magister Management Program, Mercubuana University, Jakarta, Indonesia
}

\begin{abstract}
This research aim to examine the factors that influence intention to use e-learning services. This research was conducted at Mercubuanan Universitas. The method of data collection is using primary data from 96 students who ever use e-learning through questionnaires, direct observation of the object under study and literature study by use a sample survey methodology. The data were analyzed by using SPSS 17 software. The result of analysis for this model shows that perceived easy of use and attitude affect the intention to use e-learning. This means that the intention to use e-learning is influenced by the construct perceived ease of use and attitude. The implication of this research is relevant to the management university to consider factor of perceived ease of use and attitude in applying and developing e-learning in the University system.
\end{abstract}

Keywords : E-Learning, intention, attitude, perceived ease of use, perceived usefulness.

DOI: $10.7176 / \mathrm{EJBM} / 11-21-09$

Publication date:July $31^{\text {st }} 2019$

\section{Introduction}

\subsection{Research Background}

The era of globalization is a period of full competition in an effort to improve the welfare of the nations, many opportunities will be open, but many challenges that will be faced by a nation in winning the competition. One of the main challenges in the era of globalization is preparing the young generation with good education, have high cognitive, spiritual and social abilities and are able to adapt to changing times.

The challenge of Indonesia in facing the globalization era is the low competitiveness of Indonesian people, this is marked by the low Indonesian Human Development Index when compared to other citizens of the world. The United Nations Development Program (2015) shows the low level of Indonesia's human development index. In ASEAN, Indonesia's ranking is still far below several other ASEAN member countries, such as Singapore (ranked 11th in the world). Brunei (ranked 31), Malaysia (ranked 62) and Thailand (ranked 93).

Progress in the world of education is indeed quite encouraging, because it is predicted that in 2014 all Indonesian citizens of elementary and junior high school or equivalent will surpass it, in other words the lowest Indonesian population will have senior high school education or equivalent. But the results of a survey by the international Pearson Indonesia (2013) ranking of Indonesian education compared to other countries in the World are still very low. The results of the Pearson survey of the countries in the world in 2012 stated that the quality of education in Indonesia was ranked 40th out of 40 countries surveyed, meaning that Indonesia was at the bottom of all the countries surveyed.

One way to improve the quality of education is by utilizing the advances in Communication and Information Technology (ICT). Therefore, e-learning based learning is needed as a sustainable development strategy in the world of higher education. Sustainable development in higher education is a response obtained based on scientific ethics, where technology plays an important role in sustainable development.

Research on technology, especially self-service technology has been carried out mainly, which is associated with customer attitudes and satisfaction. Meuter et. al (2000) reviews customer satisfaction with self-service technology using the CIT (critical incident technique) method. Similar research is also conducted by Selnes and Hansen (2001) which measures the effect of implementing self-service technology that replaces personal services. Mouthindo and Smith (2000) conduct research on customer satisfaction in the field of self-service technology. They see the influence of customer attitudes towards the type of bank services, both personal services and selfservice technology. This self-service technology research stops only on customer satisfaction, while measuring customer satisfaction from self-service technology related to interests is still rare. Elearning learning at the Magister Management in Mercubuanan University has not been as expected. The number of participants participating in the e-learning program in the 2015 to 2017 academic year is still between 64.21 percent and 75.26 percent. 


\subsection{Research objective and questions}

The objective of this research is to develop a model of determining the intention of students to use e-learning. This study includes the following theoretical objectives:

1. To introduce a model of determining the intention of students to use e-learning.

2. To find the relations between perceived easy of use, perceived usefulness, attitude and intention of the student in using e-learning

Based on the explanation set forth above, the research questions can be defined and formulated as follows:

1. What is the relationship between perceived easy of use and the attitude?

2. What is the relationship between perceived easy of use and the intention?

3. What is the relationship between perceived usefulness and the attitude?

4. What is the relationship between perceived usefulness and the intention?

5. What is the relationship between attitude and the intention?

\section{Theoretical Framework and Hypothesis}

\subsection{Perceive Ease of Use on Student Attitudes in Using E-learning.}

The concept of perceived ease of use shows the degree to which someone believes that the use of a new technology is easy and does not require the hard effort of the user to use it (Santoso, 2010). Perceived ease of use according to Wijana (2010) perceive ease of use means the individual belief that using an information technology system will not be troublesome or requires great effort when used. Davis (1989) defines that perceived ease as a level where one believes that the use of something will reduce one's efforts. These results support the findings of Farizi (2013) that one's belief that an information system is easy to use, then that person will decide to use or not to use the technology. Murni Y (2018) said that easiness in shopping variables were measured by six indicators; download applications easily, can register easily, order goods easily, easy to understand way of payment and done, easy to get product information purchased

Several previous studies have shown that perceived ease of use has a positive effect on the attitude of using technology. Based on empirical studies from Al-Somali et al (2008) who took research subjects in Saudi Arabia, showed that perceve ease of use influenced the attitude of users of internet banking. The sample used in this study is the Saudi Arabian people who were randomly selected. The empirical study conducted by Chau and Lai (2003) shows that perceived ease of use is positively related and has a significant effect on the use of internet banking. Ramadhani (2008) has explained that the ease of using internet banking provided by banks is easy to understand and easy to use so will reduce the customer's efforts to learn how to transact using internet banking. Individual perceptions related to ease of using computers (perceived ease of use) are the level at which individuals believe that using a particular system will be free of errors. This perception will then have an impact on behavior, namely the higher a person's perception of the ease of using the system, the higher the level of utilization of information technology (Igbaria et.al, 2000).

\subsection{Perceived Usefulness of Student Attitudes in Using E-learning.}

Juniwati (2014) showed that perceived usefulness has a significant effect on the attitude of online shopping users. The study was also supported by the descriptive statement of the research from students at universities who shop online to get better offers (anytime and anywhere) on the products offered, no need to wait and look for these products. Elkaseh et.al (2016) stated that perceptions of usefulness influence attitudes to behavior towards the use of e-learning in Lybian higher education. Al-Ghaith (2015) stated that perceptions of user usability have a positive effect on attitudes in places of social networks. The study conducted by Alharbi and Gold (2014) on academics in Saudi Arabia showed a significant influence between perceived usefulness towards the attitude of users of the learning management system (LMS).

\subsection{Perceived Ease of Use of Student Interest in Using E-learning.}

Chuchuen (2016) stated that the perceived ease of use in the mobile banking system of its customers has benefited and is accustomed to mobile banking or electronic banking applications having a high interest in using mobile banking. Zhang et.al (2015) shows the results of his research that the perception of ease of use has a positive and significant effect on consumer spending interest in new products. The results of research by Cho and Esen (2015) show that there is a significant influence on the perception of usability towards interest in online shopping. Chiu and Wang (2008) stated that perceptions of ease of use are positively related to continuous interest in the context of Web-Based learning.

Baker and stones (2015) showed the results of his research that ease of use has a positive effect on sustainable interest in the context of electronic text. Abbas and Hamdy (2015) also showed their research that ease of use has a positive effect on sustainable interest in the context of mobile service users. Lie and Liu (2014) showed their research that ease of use has a positive effect on sustainable interest in the context of online travel services. Lie 
and Wang (2012) showed the results of his research that ease of use has a positive effect on sustainable interest in the context of electronic learning. Extensive research in the previous period also showed a significant influence between the perceived ease of use of user interests both directly and indirectly (Hernande and Mazzon, 2007; Guriting and Ndubisi, 2006; Eriksson, 2005; Wang et al., 2003; Venkatesh , 2000; Venkatesh and Davis, 1996; and Venkatesh and Morris, 2000).

\subsection{Perceived Usefulness of Student Intention in Using E-learning.}

Wibowo (2008) explains that perceived usefulness is a perception of usefulness defined as a measure where the use of a technology is believed to bring benefits to those who use it. Arifin.E Achmad Fachrodji (2015) said that high and low sales of a product or brand, one of which is dependent on whether the product or item is in demand by the customer who owns it perception of the benefits and value of the product. Because of the perception of benefits and values that is what can cause purchase intention. Several previous studies have shown that perceived usefulness has a positive effect on the attitude of using technology. Chau and Lai (2003) examined empirical investigative studies that determine the acceptance of internet banking usage. Chau and Lai (2003) took the subject of research in Hong Kong, the population was students at Hong Kong Universities and the sample chosen was the executives of internet banking users. Based on empirical studies conducted by Chau and Lai (2003) it was shown that perceived usefulness was positively related and had a significant effect on the use of internet banking. Chuchuen (2016) stated that the perception of usability in the mobile banking system of its customers gain profit and are accustomed to mobile banking or electronic banking applications having a high interest in using mobile banking. The results of research by Cho and Esen (2015) show that there is a significant influence on the perception of usability towards interest in online shopping. Zhang et al (2015) showed the results of his research that perceived usefulness had a positive and significant effect on consumer spending interest in new products. Extensive research shows the significance of the relationship between perceived usefulness to adaptive interests (Chen and Barnes, 2007), (Guriting and Ndubisi, 2006), (Eriksson et al, 2005) (Hu et al., 1999) and (Venkatesh, 2000) .

\subsection{Attitudes towards Student Interest in Using E-learning.}

Attitude is a positive or negative evaluation of a person towards an object or behavior including feelings and responses that influence it (Ajzen, 1991). Iwan (2013) stated that consumer attitudes were an important factor in making purchasing decisions. There is a strong relationship between the attitude of a brand towards buying interest (Shimp \& Gresham., 1985; Homer \& Yoon, 1992; Phelps \& Hoy, 1996).

The more positive the consumer attitude towards a product, the stronger the interest in the product (Ajzen, 1991). Some research results that stated the relationship between attitudes and interests to buy organic food consistently showed a positive relationship. As stated by Thogersen (2007) and Chen (2009) indicate a positive attitude to encourage consumers to buy organic food. Irianto (2015) predicts that attitudes toward organic food affect the intention to buy organic food positively.

Davis et al (1989) who developed a model of acceptance of information technology systems known as the Technology Acceptance Model (TAM), their argued that decisions made by individuals to receive an information technology is a conscious action that can be explained and predicted by the behavior interest, while technology users will have an interest in using technology if they feel the technology system is useful and easy to use. Their stated also that a person will perform a behavior if they have the desire or interest (behavioral intention) to do it. Venkatesh, et al. (2003) examined theories about the acceptance of technology by users of a new system or technology, in the end the study concluded that there were four constructs in interest in using new technologies namely user attitudes (performance expectations and business expectations), social influences and conditions that facilitate it. Hendrian and Shine (2019) showed that positive attitude of housewives to behavior shop for counterfeit/fake products, affect his intention to go back to shopping for the product. The results of the data analysis showed a significant $\mathrm{CR}$ value $(\mathrm{CR}=5,053)$ and the standardized factor value loading of 0.281 . This figure shows that attitudes toward shopping behavior counterfeit/fake products have a positive influence on the intention to repurchase counterfeit/fake products. Agustina et.al (2016) said that consumer attitudes towards advertising have influence big and positive towards consumer buying interest

\subsection{Development of Hypotheses and Research Framework}

Based on previous theory reviews, the research hypothesis is proposed as follows:

H1: Perceived easy of use affects the attitude of e-learning users

H2: Perceived usefulness influences the attitude of e-learning users.

H3: Perceived easy of use affects the interest of e-learning users

H4: Perceived usefulness affect the interests of e-learning users

H5: Attitude affects the interest of e-learning users 


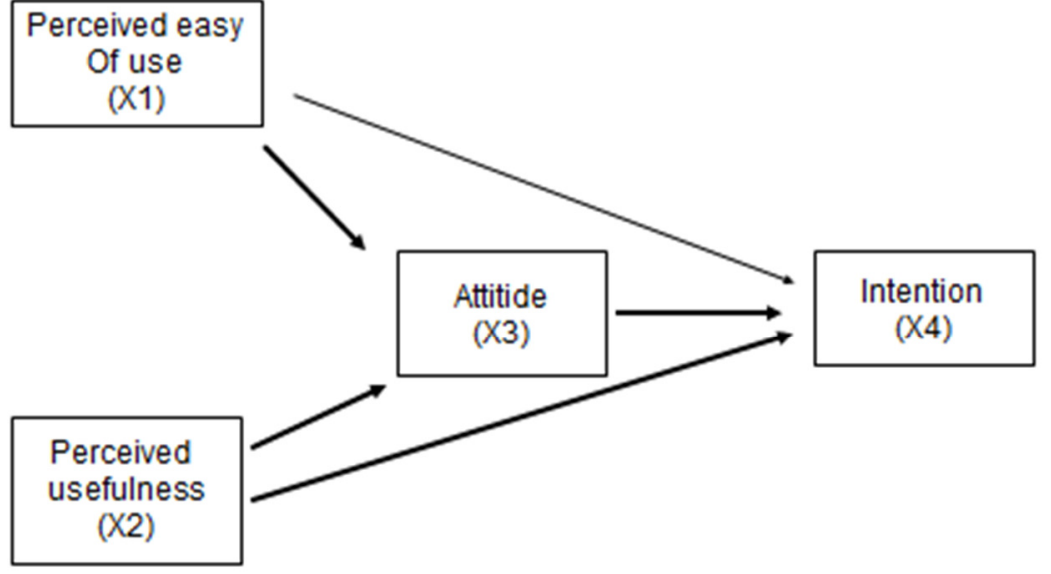

Figure 2.1. Research Model

\section{Research methods}

The type of research used is conclusive design research, namely the type of inference research that aims to test a particular hypothesis, both through in-depth research on a problem (descriptive) and looking for relationships between variables (correlative) between the independent variable and the dependent variable. In this study researchers distributed questionnaires to 96 students who took e-learning courses at the University of Mercubuana

\section{Research Results and Discussion of Research}

\subsection{Test Validity and Reliability}

This research was previously preceded by a trial of distributing questionnaires that had been made to respondents as many as 30 people. Then the data obtained from 30 respondents were tested first for validity and reliability using SPSS. We can see the validity test through the SPSS program in the Corrected Item-Total Correlation column, but in the table below we have summarized the comparison with $\mathrm{r}$ table.

Table. 4.1. Validity and Reliability Test, Perceived Ease of Use, Perceived Usefulness and Interest of Users

\begin{tabular}{|c|c|c|c|}
\hline Variabel & Indicator & Validity & Cronbach's Alpha \\
\hline \multirow{4}{*}{$\begin{array}{l}\text { Perceived easy } \\
\text { Of use (X1) }\end{array}$} & $\mathrm{X} 1.1$ & 0.813 & \multirow[t]{4}{*}{0,824} \\
\hline & $\mathrm{X} 1.2$ & 0.814 & \\
\hline & $\mathrm{X} 1.3$ & 0.855 & \\
\hline & $\mathrm{X} 1.4$ & 0.764 & \\
\hline \multirow[t]{4}{*}{ Perceived Usefulness (X2) } & $\mathrm{X} 2.1$ & 0,743 & 0,815 \\
\hline & $\mathrm{X} 2.2$ & 0,879 & \\
\hline & $\mathrm{X} 2.3$ & 0,881 & \\
\hline & $\mathrm{X} 2.4$ & 0,745 & \\
\hline \multirow[t]{4}{*}{ Attitude (X3) } & $\mathrm{X} 3.1$ & 0,833 & 0,867 \\
\hline & $\mathrm{X} 3.2$ & 0,855 & \\
\hline & X3.3 & 0,797 & \\
\hline & X3.4 & 0,895 & \\
\hline \multirow[t]{5}{*}{ Intention (X4) } & $\mathrm{X} 4.1$ & 0,858 & \multirow[t]{5}{*}{0,869} \\
\hline & $\mathrm{X} 4.2$ & 0,842 & \\
\hline & $\mathrm{X} 4.3$ & 0,676 & \\
\hline & $\mathrm{X} 4.4$ & 0,872 & \\
\hline & $\mathrm{X} 4.5$ & 0,846 & \\
\hline
\end{tabular}

Source: SPSS Processing Results

All the indicators the questions above have met the requirements and can be declared valid because $\mathrm{r}$ count is greater than table (0.361). Measurement of reliability has met the standard because all Cronbach's alpha values are greater than 0.7, so that this research can be stated to be reliable (reliable). (Easy Perception to Use of 0.824, usability perception of 0.815 , attitude of 0.867 and interest of 0.869 . 


\subsection{Classic assumption test}

\subsubsection{Normality test}

The normality test uses the Kolmogorov-SmirnovTest One Sample (with the SPSS program). Among them are the samples that will be used for analysis must come from populations that are normally distributed with a significance level of $\alpha=5 \%(0.05)$, if the significance is less than 0.05 then the data distribution can be said to be abnormal. Conversely, if the significance is geater than 0.05 , the data distribution can be said to be normal.

Table 4.2. Normality Test Table Perceived Ease of Use, Perceived Usefulness, Attitude and Intention

One-Sample Kolmogorov-Smirnov Test

\begin{tabular}{|ll|r|r|r|r|}
\hline & & X1 & X2 & \multicolumn{1}{|c|}{ Y1 } & Y2 \\
\hline N & & 96 & 96 & 96 & 96 \\
Normal Parameters ${ }^{\mathrm{a}, \mathrm{b}}$ & Mean & 16.49 & 15.84 & 16.18 & 19.92 \\
& Std. Deviation & 2.571 & 2.381 & 2.326 & 3.253 \\
Most Extreme Differences & Absolute & .138 & .120 & .138 & .104 \\
& Positive & .121 & .120 & .138 & .073 \\
& Negative & -.138 & -.085 & -.096 & -.104 \\
Kolmogorov-Smirnov Z & & 1.354 & 1.173 & 1.351 & 1.019 \\
Asymp. Sig. (2-tailed) & & .051 & .128 & .052 & .251 \\
\hline
\end{tabular}

a. Test distribution is Normal.

b. Calculated from data.

From the results of normality data processing with the One Sample Kolmogorov-SmirnovTest the Asymp value is obtained. Sig (2-tailed) respectively (perceived ease of use $=0.051$ ), (perceived of usefulness $=0.128$ ), (attitude $=0.052$ ) and (interest $=0.251$ ) are greater than 0.05 , it can be said that the four variables have normal distribution.

\subsubsection{Multicollinearity Test}

In the table below, from the results of analysis and testing of model 1 paths, that is, on the two independent variables (perceived ease of use and perceived usefulness) there are no symptoms of multicollinearity. This can be seen in the calculation of the VIF calculation of the two variables, perceived ease of use $(1,127)$, and perceived usefulness $(1,127)$. Both of these variables have VIF values lessthan 10 , and tolerance values are above 0.1 , respectively, perceived ease of use $(0.887)$, and perceived usefulness $(0.887)$ so it can be concluded that there is no multicollinearity between independent variables that must be eliminated.

Table 4.3. Table Multikolenearity Test Model 1

\section{Coefficients}

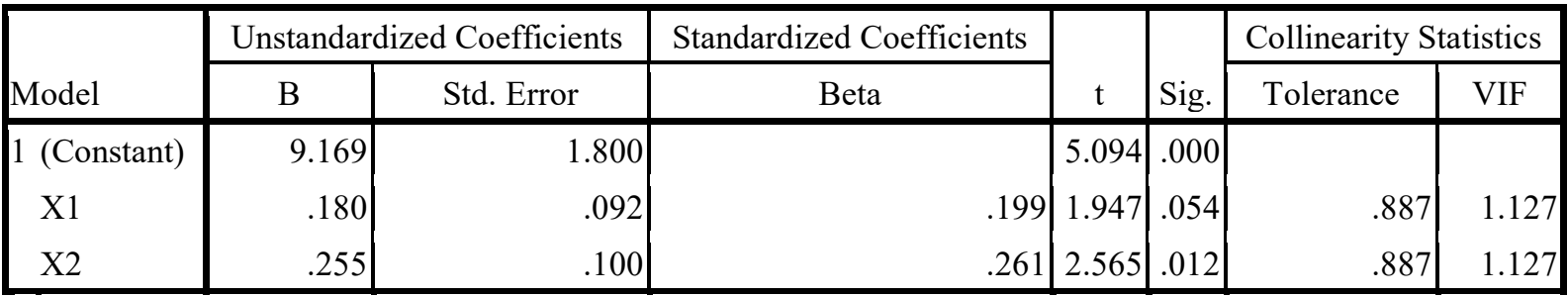

a. Dependent Variable: Y1

The table below for testing model 2 shows the tolerance value of each independent variable (perceived ease of use $=0.852$, perceived usefulness $=0.829$ and interest $=0.857$ ) is greater than 0.10 and the VIF value is less than 10 which is perceived ease of use $(1,173)$, and perceived usefulness $(1,207)$ and attitudes $(1,166)$ means that there is no correlation between independent variables so that there is no multicollinearity problem in the regression model in this study. 
Table 4.4. Table Multikolenearity Test Model 2

Coefficients $^{\mathrm{a}}$

\begin{tabular}{|c|c|c|c|c|c|c|c|}
\hline \multirow[b]{2}{*}{ Model } & \multicolumn{2}{|c|}{ Unstandardized Coefficients } & \multirow{2}{*}{$\frac{\text { Standardized Coefficients }}{\text { Beta }}$} & \multirow[b]{2}{*}{$\mathrm{t}$} & \multirow[b]{2}{*}{ Sig. } & \multicolumn{2}{|c|}{ Collinearity Statistics } \\
\hline & B & Std. Error & & & & Tolerance & VIF \\
\hline 1 (Constant) & -.029 & 2.016 & & -.014 & .989 & & \\
\hline $\mathrm{X} 1$ & .210 & .093 & .166 & 2.256 & .026 & .852 & 1.173 \\
\hline $\mathrm{X} 2$ & .089 & .102 & .065 & .870 & .387 & .829 & 1.207 \\
\hline Y1 & .932 & .103 & .666 & 9.073 & .000 & .857 & 1.166 \\
\hline
\end{tabular}

a. Dependent Variable: Y2

\subsubsection{Heteroscedasticity Test}

\section{Scatterplot}

\section{Dependent Variable: Y1}

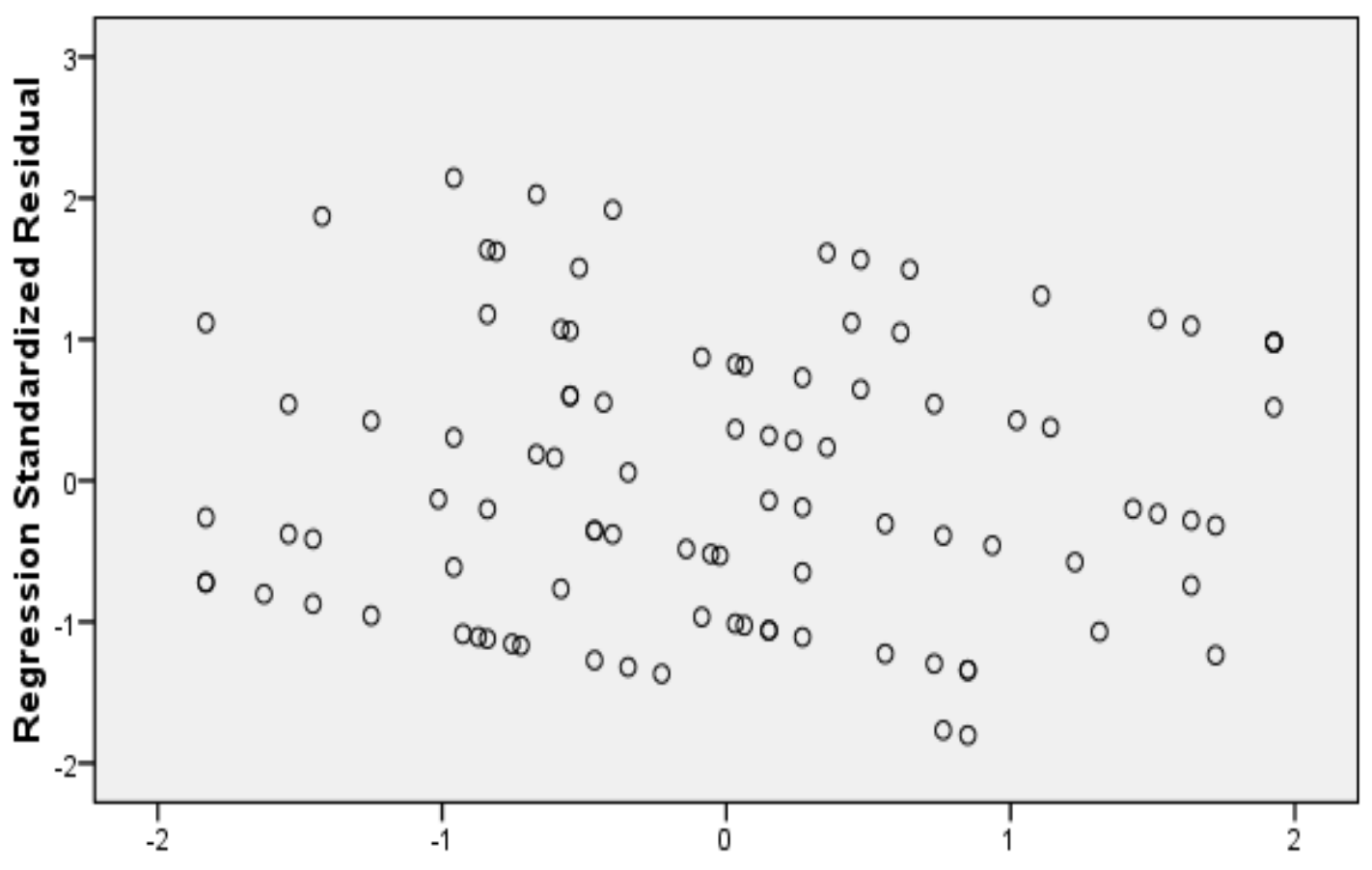

Regression Standardized Predicted Value

Figure 4.1 Graph Heteroscedasticity 1 


\section{Scatterplot}

\section{Dependent Variable: Y2}

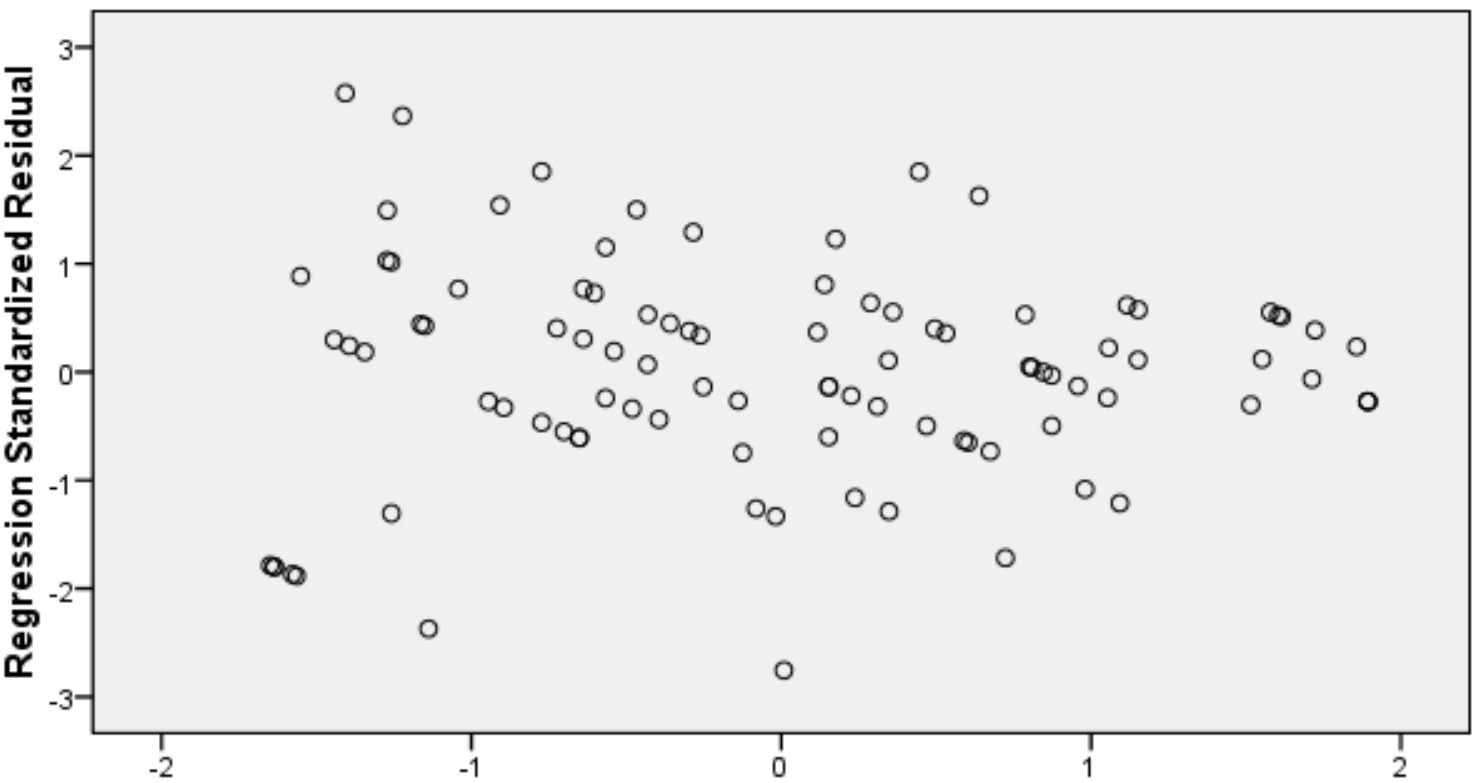

Regression Standardized Predicted Value

Figure 4.2 Graph Heteroscedasticity 2

Based on Figure 4.1 and Figure 4.2 the results of heteroscedasticity tests show that there is no clear pattern of these points, which means that there is no significant interference in path regression model 1 and model . This is seen at points above or below number 0 on the $\mathrm{Y}$ axis. It can be concluded that the data in path regression model 1 and model 2 do not experience heteroscedasticity problems, or the data has been homocedasticity.

\subsection{Path Analysis}

\subsubsection{Model Path Analysis Test Result I}

The results of testing the independent variables of product quality and brand image on customer satisfaction are shown in Table 4.5 as follows:

Table.4.5. Results of Testing the Effect of Perceived Ease of Use and Perceive Usefulness on Attitudes.

\section{Coefficients ${ }^{\mathrm{a}}$}

\begin{tabular}{|c|c|c|c|c|c|c|}
\hline \multirow[b]{2}{*}{ Model } & \multicolumn{2}{|c|}{ Unstandardized Coefficients } & \multirow{2}{*}{\multicolumn{2}{|c|}{$\frac{\text { Standardized Coefficients }}{\text { Beta }}$}} & \multirow[b]{2}{*}{$l$} & \multirow[b]{2}{*}{ Sig. } \\
\hline & $\mathrm{B}$ & Std. Error & & & & \\
\hline 1 (Constant) & 9.169 & 1.800 & & & 5.094 & .000 \\
\hline $\mathrm{X} 1$ & .180 & .092 & & .199 & 1.947 & .054 \\
\hline $\mathrm{X} 2$ & .255 & .100 & & .261 & 2.565 & .012 \\
\hline
\end{tabular}

a. Dependent Variable: Y1

Based on Table 4.5 above, the coefficients of each independent variable used can be determined as follows:

$$
\mathrm{Y} 1=0.199 \mathrm{X}_{1}+\mathbf{0 . 2 6 1 X _ { 2 }}
$$

The sig value from the influence of perceived ease of use on attitudes obtained sig value of 0.54 where the value is greater than the significance value in this study which is 0.05 . This means that the perceived ease of use has no significant effect on attitudes.

The sig value of the perception of usability towards attitudes shown in Table 4.5 is 0.012 where the value is smaller than the 0.05 significance value. This means that the value of perceived usefulness has a significant effect on attitudes. This is in line with previous research as shown by Elkaseh et al. (2016) stating the perception of usability influences attitudes to behavior towards the use of e-learning in Lybian higher education. Al-Ghaith (2015) stated that perceptions of user usability have a positive effect on attitudes in places of social networks. The study conducted by Alharby and Gold (2014) on academics in Saudi Arabia showed a significant influence 
between perceived usefulness towards the attitude of users of the learning management system (LMS).

\subsubsection{Model Path Analysis Test Result II}

The results of testing independent variables perceived ease of use, perceived usefulness, and attitudes toward interests are shown in Table 4.6 as follows:

Table 4.6 Results of Testing Perceived Ease of Use, Perceive Usefulness and Attitudes toward Intention

\section{Coefficients $^{\mathbf{a}}$}

\begin{tabular}{|c|c|c|c|c|c|}
\hline \multirow[b]{2}{*}{ Model } & \multicolumn{2}{|c|}{ Unstandardized Coefficients } & \multirow{2}{*}{$\begin{array}{c}\text { Standardized Coefficients } \\
\text { Beta }\end{array}$} & \multirow[b]{2}{*}{$\mathrm{t}$} & \multirow[b]{2}{*}{ Sig. } \\
\hline & B & Std. Error & & & \\
\hline (Constant) & -.029 & 2.016 & & -.014 & .989 \\
\hline $\mathrm{X} 1$ & .210 & .093 & .1 & 2.256 & .026 \\
\hline $\mathrm{X} 2$ & .089 & .102 & .0 & .870 & .387 \\
\hline Y1 & .932 & .103 & & 9.073 & .000 \\
\hline
\end{tabular}

a. Dependent Variable: Y2

The sig value from the influence of perceived ease of use on interest obtained sig value of 0.026 where the value is smaller than the significance value in this study which is 0.05 . This means that the perceived ease of use has a significant effect on interest. The same thing is also shown by the research of Zhang et al. (2015) which shows the results of his research that the perceived ease of use has a positive and significant effect on consumer spending interest in new products. Baker and stones (2015) showed the results of his research that perceived ease of use has a positive effect on sustainable interest in the context of electronic text. Abbas and Hamdy (2015) also showed their research that the perceived ease of use has a positive effect on sustainable interest in the context of mobile service users. Lie and Liu (2014) showed their research that the perceivedease of use has a positive effect on sustainable interest in the context of online travel services.

The sig value of the perceived usefulness of interest is 0.387 where the value is greater than the significance value of 0.05 . This means that the perceived usefulness has no significant effect of intention.

The sig value of the attitude towards interest is 0,000 where the value is smaller than the 0.05 significance value. This means that the attitude has a significant effect on intention. This is in line with previous research as shown by the more positive consumer attitudes towards a product, the stronger the interest in the product (Ajzen, 1991). Research on the attitude of users in looking at a new technological development that influences intention in using Davis et al (1989) who developed a model of acceptance of information technology systems known as the Technology Acceptance Model (TAM), their argued that decisions made by individuals to receive an information technology is a conscious action that can be explained and predicted by the behavior interest, while technology users will have an interest in using technology if they feel the technology system is useful and easy to use. Their stated also that a person will perform a behavior (behavior) if they have the desire or interest (behavioral intention) to do it.

\section{Conclusion}

\subsection{Managerial implications}

Perceived ease of use have a strong influence and significant on the intention in learning e-learning. For this reason, in attracting e-learning learning interest for students, it is necessary to pay attention to positive attitudes such as students feel happy and useful in using e-learning and perceived ease of use such as ease of use and ease of learning e-learning.

\subsection{Contributions to theory}

The results showed that perceived usefulness had a significant positive effect on attitudes. This is in line with previous research as shown by Elkaseh et al. (2016) stated the perceived usefulness influences attitudes to behavior towards the use of e-learning in Lybian higher education. Al-Ghaith (2015) stated that perceived usefulness have a positive effect on attitudes in places of social networks. The study conducted by Alharby and Gold (2014) on academics in Saudi Arabia showed a significant influence between perceived usefulness towards attitudes of learning management system users (LMS)

The results of the study on the perceived ease of use have a significant positive effect on intention. The same thing is also shown by the research of Zhang et al. (2015) which showed the results of his research that the perceived ease of use has a positive and significant effect on consumer spending intention in new products. Baker and stones (2015) showed the results of his research that perceived ease of use has a positive effect on sustainable intention in the context of electronic text. Abbas and Hamdy (2015) also show their research that the perceived ease of use has a positive effect on sustainable intention in the context of mobile service users. Lie and Liu (2014) show their research that the perceived ease of use has a positive effect on sustainable intention in the context of 
online travel services.

The results of the research on attitudes have a positive and significant effect on intention. This is in line with previous research as shown by the more positive consumer attitudes towards a product, the stronger the intention in the product (Ajzen, 1991). Research on the attitude of users in looking at a new technological development that influences intention in using, Davis et al (1989) who developed a model of acceptance of information technology systems known as the Technology Acceptance Model (TAM), they argued that decisions made by individuals to receive an information technology is a conscious action that can be explained and predicted by the behavior intention, while technology users will have an intention in using technology if they feel the technology system is useful and easy to use. They stated also that a person will perform a behavior (behavior) if they have the desire or intention (behavioral intention) to do it.

\subsection{Research Limitations}

The results of this study do not examine other variables that influence interest such as value, learning media or other variables. The results of this study were conducted only on one college, namely the university of mercubuana so that it does not apply generally to every college.

\subsection{Advanced Research Direction}

Further research needs to be developed with the object of research not only in one college, but with the object of research in several universities so that the results can be generalized for each college. Subsequent research can also explore other independent variables that have not been studied in this study.

\section{REFERENCES}

Abbas, H. A., Hamdy, H. I. 2015. Determinants of continuance intention factor in Kuwait communication market: Case study of Zain-Kuwait. Computers in Human Behavior, 49(0), 648-657.

Agustina. D, Mukhamad Najib, and Budi Suharjo (2016). The Effect of Online Advertising Personalization on An Attitides and Intention for Buying Consumers. MIX: Jurnal Ilmiah Manajemen, Volume VI, No. 3, p. 367386

Ajzen, I. (1991). The Theory of Planned Behavior. Organizational Behavior and Human Decision Processes, 50(2): 179-211.

Al Ghaith Waleed (2015). Applying the Technology Acceptance Model to Understand Social Net Working Sites (SNS) Usage: Impact of Perceived Social Capital. International Journal of Computer Science \& Information Technology (IJCSIT) Vol 7, No 4, August 2015.

Alharbi S and Gold Coast (2014). Using the Technology Acceptance Model in Understanding Academics' Behavioural Intention to Use Learning Management Systems. International Journal of Advanced Computer Science and Applications, Vol. 5, No. 1, 201,p.143-155

Al-Somali, S.A, Gholami, R., and Clegg, B. 2008. An investigation into the acceptance of online banking in Saudi Arabia. Technovation, vol. 29, pp. 130141.

Arifin.E and Achmad Fachrodji (2015). The Effect of perception of Product Quality, Brand Image and Promotion Against Intention in Buying Ban Archilles Consumers in South Jakarta. Jurnal MIX, Volume V, No. 1, p. $124-143$

Baker-Eveleth, L., Stone, R. W. 2015. Usability, expectation, confirmation, and continuance intentions to use electronic textbooks. Behaviour \& Information Technology, 1-13.

Chau, P.Y.K. and Lai, V.S.K. 2003. An empirical investigation of the determinants of user acceptance of internet banking. Journal of Organizational Computing \& Electronic Commerce. Vol. 13 No. 2, pp. 123-45.

Chen, M. (2009). Attitude toward organic foods among Taiwanese as related to health consciousness, environmental attitudes, and the mediating effects of a healthy lifestyle, British Food Journal, 111(2): 165178.

Chen YH and Barnes S (2007). Initial trust and online buyer behaviour. Ind.Manage. Data Syst. 107 (1), 21-36.

Chiu, C.-M., Wang, E. T. G. 2008. Understanding Web-based learning continuance intention: The role of subjective task value. Information \& Management, 45(3), 194-201.

Cho Yoon C and Esen Sagynov (2015). Exploring Factors That Affect Usefulness, Ease Of Use, Trust, And Purchase IntentionIn The Online Environment. International Journal of Management \& Information Systems - First Quarter 2015 Volume 19, Number 1

Chuchuen Chat (2016). The Perception of Mobile Banking Adoption: The Study of Behavioral, Security, and Trust in Thailand. International Journal of Social Science and Humanity, Vol. 6, No. 7, July 2016: 547-540

David F. D, 1989. Perceived Usefulness, Perceived Ease of Use, and User Acceptance of Information Technology", MS Quartely Vol. 13, No. 3 September.pp. 319-340

Davis, F.D, R.P. Bagozzi, dan PR. Washaw. 1989. User Acceptance of Computer Technology: A Comparison of Two Theoritical Models, International Journal Management Machine Studies, August, Vol. 35, No. 8, pp. 
982- 1003

Elkaseh Ali Mohamed, Kok Wai Wong, and Chun Che Fung (2016). Perceived Ease of Use and Perceived Usefulness of Social Media for e-Learning in Libyan Higher Education: A Structural Equation Modeling Analysis. International Journal of Information and Education Technology, Vol. 6, No. 3, March 2016.

Eriksson K, Kerem K, Nilsson D (2005). Customer acceptance of internet banking in Estonia, Int. J. Bank Mark. 23 (2), 200-216.

Farizi Hadyan. 2013. Pengaruh Persepsi Kegunaan, Persepsi Kemudahan, Persepsi Risiko dan Kepercayaan Terhadap Minat Menggunakan Internet Banking, Jurnal Keuangan dan Perbankan, Vol. 2, No. 2.

Guriting P, Ndubisi NO (2006). Borneo online banking: evaluating customer perceptions and behavioural intention. Manage. Res. News. 29 (1/2), 6-15.

Hendrian and Shine P.S.P (2019). Psychological Factors for Determining the Number of Household Moms in Indonesia to Buy Artificial/Fake Products. MIX: Jurnal Ilmiah Manajemen, Volume 9, No. 1, Februari 2019, p 88-108

Hernandez JMC, Mazzon JA (2007). Adoption of internet banking:proposition and implementation of an integrated methodology approach, International J. Bank Mark. 25 (2): 72-88.

Homer, P. M., \& Yoon, S. G. (1992). Message framing and the interrelationship among Ad-Based Feelings, Affect, and Cognitiion. (1992). Journal of Advertising. 21(1). 19-33.

Hu PJ, Chau PYK, Sheng ORL and Tam KY (1999). Examining thetechnology acceptance model using physician acceptance of telemedicine technology. J. Manage. Info. Syst. 16(2): 91-112.

Igbaria, M., Anandarajan, M., dan Anakwe, U. 2000. "Technology Acceptance in The Banking Industry: A Perspective from A Less Developed Country," Information Technology and People, MCB University Press, pp. 298-312.

Irianto. H (2015). International Journal of Management, Economics and Social Sciences 2015, Vol. 4(1), pp.17 31.

Iwan, C.Y. 2013. Pengaruh Sikap terhadap Green Advertising pada Brand Image The Body Shop antara Konsumen Domestik dan Asing. Jurnal JIBEKA, 7 (3): h:5-10.

Juniwati (2014). Influence of Perceived Usefulness, Ease of Use, Risk on Attitudeand Intention to Shop Online. European Journal of Business and Management ISSN 2222-1905 Paper) ISSN 2222-2839 (Online) Vol.6, No.27

Li, H., Liu, Y. 2014. Understanding post-adoption behaviors of e-service users in the context of online travel services. Information \& Management, 51(8), 1043-1052.

Lie, W.-S., Wang, C.-H. 2012. Antecedences to continued intentions of adopting e-learning system in blended learning instruction: A contingency framework based on models of information system success and tasktechnology fit. Computers \& Education, 58(1), 88-99. Jogiyanto. 2007. Sistem Teknologi Informasi. Yogyakarta.

Meutter, L. M., Ostrom, A.L., Roundtree, R. L., and Bitner, M. J. (2000). Self Service Technology: Understanding Customer Satisfaction with Technology-Based Service Encounter". Journal of Marketing. 64 (No.3) 50-64.

Moutinho, L., and Smith ,A (2000), Modeling bank customer satisfaction through mediation of attitude towards human and automated banking": International Journal of Banking Marketing. 18 (No. 3), 124-134.

Murni Y (2018). Analysis of the Influence of Trust, Easiness in Shopping, Product Quality to Customer Satisfaction to Increaseness in Shopping Customer Loyalty Online Shopping. International Journal of Economics, Business and Management Research, Vol.2, No. 04, p. 50-64

Phelps, J. E., \& Hoy, M. G. (1996). The Aad-Ab-PI Relationship in children: the impact of brand familiarity and measurement timing. Psychology \& Marketing, Vol. 13(1). 77-101

Ramadhani, R. 2008. Analisis Faktor Faktor yang Mempengaruhi Penerimaan Nasabah Terhadap Layanan Internet Banking di Semarang : Dengan Menggunakan Pendekatan TAM. Skripsi. Universitas Islam Indonesia.

Salnes, F, and Hansen, H. (2001), The Potential Hazard of Sels Service in Developing Customer Loyalty, Journal of Service Research, 4 (No.2), 79-90.

Santoso Budi. 2010. Pengaruh Perceived Usefulness, Perceived Ease of Use, dan Perceived Enjoyment Terhadap Penerimaan Teknologi Informasi: Studi Empiris di Kabupaten Sragen. Tesis Fakultas Ekonomi Universitas Sebelas Maret

Shimp, T. A., \& Gresham, L. G. (1985). Attitude toward the advertisement and brand attitudes: a classical conditioning perspective. Journal of Advertising. Vol. 14 (1). 10-18.

Thøgersen, J. (2007). Consumer decision making with regard to organik food products. In Vaz, M.T.D.N., Vaz, P., Nijkamp, P. \& Rastoin, J.L. (Eds), Traditional food production facing sustainability: A European challenge, Ashgate: Farnham.

Venkatesh V (2000). Veterminants of perceived ease of use: integrating control, intrinsic motivation, and emotion into the technology acceptance model. Info. Syst. Res. 4(4): 342-365.

Venkatesh V and Davis FD (1996). A model of the antecedents of perceived ease of use: development and test. 
Decis. Sci. 27(3), 451- 481.

Venkatesh A and Morris MG (2000). Why don't men ever stop to ask for directions? gender, social influence, and their role in technology acceptance and usage behavior. MIS Quarterly, 24(1): 115-139.

Venkatesh, V., Morris, M.G., Davis, G.B. dan Davis, F.D. 2003. "User Acceptance of Information Technology: Toward A Unified View", MIS Quarterly, Vol. 27, No. 3, pp. 425-78.

Wang Y, Wang Y, Lin H, Tang T (2003). Determinants of user acceptance of internet banking: an empirical study. Int. J. Service. Ind. Manage. 14(5), 501-519.

Wibowo, A. 2008. Kajian Tentang Perilaku Pengguna Sistem Informasi dengan Pendekatan Technology Acceptance Model (TAM). Program Studi Sistem Informasi, Fakultas Teknologi Informasi, Universitas Budi Luhur.

Widjana Mahardika Aditya. 2010. Determinan Faktor Penerima terhadap Internet banking pada Nasabah Bank di Surabaya.Tesis. Surabaya. Sekolah Tinggillmu Ekonomi Perbanas.

United Nations Development Program 2015. Human Development Report 2015. Work for Human Development. UNDP.

Zhang Yong, Gang Wan, Liuting Huang and Qiong Yao (2015). Study on the Impact of Perceived Network Externalities on Consumers' New Product Purchase Intention. Journal of Service Science and Management, 2015, 8, 99-106. 